\title{
АДМІНІСТРАТИВНІ ПРАВОПОРУШЕННЯ У ТОРГОВЕЛЬНІЙ ДІЯЛЬНОСТІ, ПОВ'ЯЗАНІ ЗІ ЗДІЙСНЕННЯМ ДИСТАНЦІЙНИХ РОЗРАХУНКІВ
}

Куварзін О. С.

Стаття присвячена визначенню суттєвих властивостей адміністративної відповідальності у сфері торговельної діяльності, пов'язаної зі здійсненням дистанційних розрахунків. Автор зазначає, що система адміністративноі відповідальності включає до себе групу адміністративних деліктів, об'єктом яких є суспільні відносини в економічній сфері.

Автор обгрунтовує, що адміністративні правопорушення, які містяться у Кодексі України про адміністративні правопорушення, характеризуються певною застарілістю своїх положень і не відповідають сучасному етаnу розвитку суспільних відносин. Це свідчить про необхідність вдосконалення адміністративно-деліктного законодавства з урахуванням тенденцій розвитку платіжних систем i підтверджує необхідність проведення більш глибоких досліджень об'єктивної сторони адміністративних правопорушень у сфері дистанційних розрахунків.

Ключові слова: адміністративна відповідальність, адміністративні делікти, дистанційні розрахунки, адміністративні правопорушення, торгівельна діяльність.

Статья посвящена определению существенных свойств административной ответственности в сфере торговой деятельности, связанной с осуществлением дистанционных расчетов. Автор заявляет, что система административной ответственности включает в себя группу административных деликтов, объектом которых являются общественные отношения в экономической сфере.

Автор обосновывает, что административные правона рушения, содержащиеся в Кодексе Украины об административных правонарушениях, характеризуются определенной устарелостью своих положений и не соответствуют современному этапу развития общественных отношений. Это свидетельствует о необходимости совершенствования административно-деликтного законодательства с учетом тенденций развития платежных систем и подтверждает необходимость проведения более глубоких исследований объективной стороны административных правонарушений в сфере дистанционных расчетов.

Ключевые слова: административная ответственность, административные деликты, дистанционные расчеты, административные правонарушения, торговая деятельность.

The article is devoted to the determination of the essential properties of administrative responsibility in the field of trading activities related to the implementation of distance settlements. The author substantiates that an effective mechanism of administrative responsibility for offenses in the field of distance trading acts as a means of preventing the commission of mercenary crimes, as well as the legalization (laundering) of proceeds from crime, the financing of terrorism and the financing of the proliferation of weapons of mass destruction.

Куварзін О. С., 2019
The article established that administrative responsibility is a phenomenon that is designed primarily to educate subjects of public relations in the spirit of strict observance of legal requirements. The author focuses on the fact that the legislation in the field of distance trading and administrative-tort legislation in this area are characterized by the presence of gaps and contradictions. The author emphasizes the need for continuous monitoring of national legislation in order to determine the degree of compliance with the current stage in the development of public relations, trading practices and the development of information technologies.

The article concludes that administrative responsibility for offenses in the field of remote settlements acts as a guarantee of legality in the system of economic relations and is a condition for counteracting the legalization (laundering) of proceeds from crime, the financing of terrorism and the financing of the proliferation of weapons of mass destruction. The system of administrative responsibility includes a group of administrative tort, the object of which is public relations in the economic sphere.

The author substantiates that administrative offenses, contained in the Code of Ukraine on administrative offenses, are characterized by a certain obsolescence in their provisions and do not correspond to the current stage of development of public relations. This indicates the need to improve administrative-tort legislation, taking into account trends in the development of payment systems and confirms the need for more in-depth studies of the objective side of administrative offenses in the field of distance payments.

Key words: administrative responsibility, administrative tort, distance settlements, administrative offenses, trading activities.

Постановка проблеми та їі актуальність. Протягом останніх років у нашій державі гостро постала проблема удосконалення законодавства, яке регулює порядок проведення готівкових розрахунків. Тінізація економічних відносин досягла в Україні загрозливих масштабів, тому вжиття державою невідкладних заходів для зміни такого становища $є$ одним із нагальних завдань економічної та правової політики. Заходи, спрямовані на детінізацію відносин у сфері підприємницької діяльності, включають у тому числі й питання щодо адміністративних деліктів, пов'язаних із порушенням порядку готівкових розрахунків. Особливо актуальним це питання $\epsilon$ сьогодні, коли готуються масштабні зміни системи кримінального законодавства, пов'язані із введенням кримінальних проступків, і висловлюються припущення про доцільність ліквідації інституту адміністративної відповідальності. У поєднанні із недостатньою дослідженістю проблем дистанційних розрахунків в адміністративно-правовій науці вказане обумовлює актуальність теми наукової статті.

Аналіз останніх досліджень і публікацій. Проблематика удосконалення системи адміністративної від- 
повідальності привертала увагу науковців О.В. Аніна, І.А. Бережної, Ю.П. Битяк, В.А. Біленко, Д.Д. Бойко, М.Ю. Букрєєва, Я.В. Ващук, М.М. Вовчук, І.В. Казачук, Є.В. Кириленко, В.К. Колпакова, В.А. Крижановської, О.В. Кузьменко, О.І. Савченко, А.О. Собакарь, А.В. Червінчук, О.В. Шевцова, С.А. Шепетько, В.К. Шкарупи та інших дослідників. Разом із тим питання удосконалення адміністративної відповідальності за порушення порядку проведення дистанційних розрахунків ще не здобуло достатнього висвітлення в адміністративно-правовій науці.

Метою статті $€$ визначення суттєвих властивостей адміністративної відповідальності у сфері торговельної діяльності, пов'язаної зі здійсненням дистанційних розрахунків.

Виклад основного матеріалу. Останнім часом економічні відносини в Україні динамічно змінюються під впливом нових інформаційних технологій. Як зазначають науковці, в умовах посилення інноваційно-технологічного розвитку світового господарства сфера торгівлі справедливо вважається важливим середовищем для інновацій і пошуку ефективних механізмів як в частині формування свого сучасного інформаційно-технологічного базису, так і в межах системи відносин із покупцями. Інноваційний підхід дозволяє по-новому бачити ринок і створювати та впроваджувати нові ефективні інструменти роботи на ньому.

Сьогодні в передових компаніях інноваційні підходи застосовуються при вирішенні питань інфраструктури роздрібної торгівлі, включаючи сучасні формати підприємств, використання інноваційного маркетингу, IT-технологій та іншого. В оптовій торгівлі широко застосовуються технологічні інновації для формування сучасної матеріально-технічної бази, інновації в логістиці та інтернет-технології [1, с. 76]. Використання дистанційних операцій під час торгівлі значно підвищує ефективність багатьох бізнес-процесів і дає змогу швидко та якісно задовольнити потреби споживачів у певних товарах і послугах, які, можливо, відсутні в регіонах їх мешкання. Така простота та зручність породжують і умови для вчинення шахрайських дій, пов'язаних із заволодінням коштами осіб, які здійснюють купівлю певних товарів чи послуг по передоплаті.

Серед науковців тривають дискусії щодо назви виду торгівлі на відстані, яка здійснюється за допомогою сучасних інтернет-технологій. Так, висловлюються думки про існування електронної торгівлі, під якою розуміють продаж матеріальних і нематеріальних цінностей в електронний спосіб. Існує позиція й щодо того, що співвідношення понять «електронна комерція» та «електронна торгівля» говорить про їх тісний взаємозв'язок. Це пояснюється тим, що в правовому полі ці поняття мають тотожне значення, а найбільшу перешкоду для їх розуміння чинять мовні аспекти перекладу терміну «електронна торгівля» $з$ англійської, де найбільш вживаним $є$ поняття “е-commerce".

Прихильники думки про розмежування вказаних категорій вважають, що оскільки електронна комерція, якщо розглядати іï глобально, може бути співставлена терміну «електронний бізнес» як підприємницька діяльність суб'єктів економічних відносин, електронна торгівля такого співставлення не витримує. 3 іншого боку електронна комерція в більш локальному значенні як процес обміну, купівлі, продажу товарів та послуг із застосуванням інформаційно-комунікаційних технологій може бути рівнозначна електронній торгівлі, а остання розглядатися як окремий випадок електронної комерції [2].

Автор зауважує, що термін «електронний» хоч і вживається у багатьох зарубіжних і вітчизняних наукових джерелах і навіть правових актах, у цьому випадку не може бути визнаний науково коректним: електрони як негативно заряджені елементарні частинки жодної торгівельної діяльності вести не можуть, а технології, які базуються на процесі взаємодії електронних потоків з електромагнітними полями, вийшли з ужитку у цивілізованому світі більш ніж 30 років тому внаслідок більшої ефективності цифрових технологій. Тому термін «дистанційна торгівля» автор вважає більш коректним. Конкретні види дистанційної торгівлі залежать від використання в ній певних платіжних механізмів (від накладеного платежу до оплати криптовалютами).

Проведений фахівцями Великої Британії аналіз шахрайства в електронній комерції (The Nilsen Report, 2015) показав, що найбільш поширеними видами шахрайства, які викликають максимальне занепокоєння, $\epsilon$ крадіжки персональних даних identity theft (71\%), фішинг phishing (66\%) і злом аккаунта account theft (63\%). Кредитні картки $€$ найпопулярнішим об'єктом, оскільки шахрай може виконати транзакцію без наявності картки.

Загалом при крадіжці персональних даних (identity theft) метою шахраїв $\epsilon$ проведення транзакцій під чужим іменем. У разі вчинення крадіжки персональних даних (identity theft) метою шахраїв зазвичай $\epsilon$ особисті дані, такі як імена, адреси електронної пошти та адреси електронної пошти, а також дані кредитних карт або інформація про аккаунт (рахунок). Це дозволяє шахраям, наприклад, здійснювати замовлення товарів в інтернеті під чужим іменем і оплачувати їх, використовуючи чужу кредитну карту або списувати кошти з чужого рахунку. Фішинг (phishing) включає в себе використання фіктивних веб-сайтів, електронної пошти або текстових повідомлень для доступу до персональних даних. $€$ й інший метод, відомий як фарминг (pharming), коли фіктивні сторінки в браузері перенаправляють клієнтів на веб-сайт шахраїв, де такі клієнти вводять свої паролі та конфіденційні дані, вважаючи, що вони знаходяться на захищеній веб-сторінці їх банку або надійного інтернет-магазину [3, с. 38].

Існує й можливість фінансування незаконної діяльності, зокрема терористичної, що за умов здійснення дистанційної торгівлі не завжди може бути оперативно та достовірно встановлено. Тому потребує вдосконалення система державного контролю за наявністю або відсутністю у заходах дистанційної торгівлі складів кримінальних злочинів. Вказане обумовлює необхідність більш пильної уваги держави за дотриманням правових приписів під час здійснення дистанційної торгівлі, адже тривала безконтрольна діяльність із порушенням норм законодавства може призводити до виникнення у суб'єктів правовідносин хибного уявлення про їх безкарність, що може сприяти вчиненню ними кримінальних правопорушень і надалі. Тому ефективним механізмом адміністративної відповідальності за правопорушення у сфері дистанційної торгівлі $\epsilon$ засіб попередження вчинення корисливих злочинів, а також легалізації (відмивання) доходів, одержаних злочинним 
шляхом, фінансування тероризму та розповсюдження зброї масового знищення.

Адміністративна відповідальність $\epsilon$ феноменом, покликаним перш за все здійснювати виховання суб'єктів суспільних відносин в дусі неухильного дотримання правових приписів. Якщо законодавство у сфері дистанційної торгівлі та адміністративно-деліктне законодавство у вказаній сфері характеризуються наявністю прогалин і суперечностей, то замість виховного ефекту, метою якого $\epsilon$ підвищення рівня правової культури, можна отримати прямо протилежні наслідки.

Через суперечливості правових норм у правокористувачів може складатися враження про безглуздість правових приписів, зростатиме рівень їх правового нігілізму. Для того, щоб така ситуація залишалася чисто гіпотетичною, необхідно постійно проводити моніторинг національного законодавства з метою визначення ступеня його відповідності сучасному етапу розвитку суспільних відносин, практик торгівельної діяльності та розвитку інформаційних технологій.

Висновки. На підставі викладеного вище можна зробити висновок, що адміністративна відповідальність за правопорушення у сфері дистанційних розрахунків $\epsilon$ запорукою законності у системі господарських відносин, умовою протидії легалізації (відмиванню) доходів, отриманих злочинним шляхом, фінансуванню тероризму та розповсюдження зброї масового знищення.

Система адміністративної відповідальності включає до себе групу адміністративних деліктів, об'єктом яких $\epsilon$ суспільні відносини в економічній сфері. Адміністративні правопорушення, які містяться у Кодексі України про адміністративні правопорушення, характеризується певною застарілістю своїх положень і не відповідають сучасному етапу розвитку суспільних відносин та особливостям інформаційних технологій. Це свідчить про необхідність вдосконалення адміністративно-деліктного законодавства з урахуванням тенденцій розвитку платіжних систем і підтверджує необхідність проведення більш глибоких досліджень об'єктивної сторони адміністративних правопорушень у сфері дистанційних розрахунків.

\section{Література}

1. Інноваційний розвиток підприємств сфери торгівлі: світові тенденції та практика в Україні : монографія / С.А. Давимука, Л.І. Федулова, Н.М. Попадинець та ін.; за заг. ред. С.А. Давимуки. Львів : ДУ «Інститут регіональних досліджень імені М.І. Долішнього НАН України». 432 с.

2. Маловичко С.В. Наукові підходи до визначення електронної торгівлі. Наука й економіка. 2016. № 1. С. 33-39.

3. Найпопулярніші способи шахрайства в електронній комерції. URL: https://uteka.ua/ua/publication/ news-14-delovye-novosti-36-samye-populyarnye-sposobymoshennichestva-v-elektronnoj-kommercii (дата звернення: 12.07.2017).

Куварзін О. С., аспірант кафедри адміністративного, фінансового і банківського права Навчально-наукового інституту права імені князя Володимира Великого Міжрегіональної Академії управління персоналом 